\title{
Inflation, Unemployment, and Economic Growth: Implication on Poverty Level in Bengkulu Province
}

\author{
Ratu Eva Febriani ${ }^{1}$, Yefriza ${ }^{2}$, Retno Agustina Ekaputri ${ }^{3}$, Antoni Sitorus ${ }^{4}$, Novi Tri Putri ${ }^{5}$ \\ Faculty of Economics, Universitas Bengkulu, Bengkulu, Indonesia \\ \{ratuevafebriani@unib.ac.id ${ }^{1}$, yefriza147@gmail.com², retnoae@unib.ac.id ${ }^{3}$ \}
}

\begin{abstract}
This paper aims to investigate the role of inflation, unemployment, and economic growth in explaining the prevalence of poverty in Bengkulu Province. The study used a time series data for 26 years (1992-2017). The data were secondarily sourced from statistics bureau. Ordinary least square (OLS) was used as an analytical technique. Empirical results show that inflation and unemployment have positive and economic growth has negative impact on poverty. The paper recommends to applied an appropriate macroeconomic policy which is crucial for poverty alleviation. To improve economic growth, efforts must be put in place to increase productivity; improving the level of local production. To restrain the surging rate of unemployment, it is necessary to creates a work training center, opening new economic centers, and linking education and skills needed in the labor market. Furthermore, there must be concrete efforts to controlling inflation, because inflation affects poverty mainly through its impact on real wage. In other word, inflation affects people's purchasing power.
\end{abstract}

Keywords: Poverty; Inflation; Unemployment; Growth; Bengkulu Province

\section{Introduction}

Macroeconomic indicators are always used as a reference in viewing development in an area. The most widely used macroeconomic indicators are economic growth, poverty, inflation, and unemployment. This happened in the search results via Google on June 2, 2018, 18,100 news related to economic growth in Bengkulu Province presented, for the poverty variable there was 8,750 news, then there were 5,950 inflation news and 3,080 news about unemployment. These results are only for reporting, especially, open the type of information about macroeconomic indicators, so search results through Google will display hundreds of thousands of results.

This fact shows that the four macroeconomic indicators play an important role in the economy. Their involvement in the development process has interactions with one another. Each variable has an attachment and can influence each other. However, this study will focus more on the interaction of inflation, economic growth, and unemployment in the society. This is because it is in accordance with what is mandated in the 1945 Constitution which states that "Earth, air and natural resources contained therein are controlled by the state and used for the 
greatest prosperity of the people". This article implies that all existing natural resources must be managed properly and properly so as to create a prosperous society, that is, poverty can be eliminated.

To be able to reduce the level of poverty, it is necessary to pay attention to the movement of economic factors such as inflation, unemployment, and economic growth. Economists have mixed opinions about the impact of inflation on people's welfare. In fact, it has to do with why inflation does not pay attention to society; Inflation reflects the increase in prices continuously over a certain period of time. This means that when the prices of basic necessities and services increase, it will be difficult for poor people with limited income to consume these goods and services. The limited purchasing power of the poor will shrink when the price of commodities increases while their income does not increase or increase but not in the same magnitude as the increase. Many people do not realize that inflation is a hidden tax which is very damaging because inflation will reduce the purchasing power of the money we have, thus making us poor even if we have the same amount of money in the bank or in our pockets [1].

Inflation increases poverty in two ways; First, inflation is like other forms of tax, meaning that inflation will reduce disposable income earned by the public. Second, if the nominal wage is lower than the price of goods consumed by wage earners, the real income of workers will decrease. So, unconsciously, inflation affects the net income that can be consumed by the community and it is very influential with the purchasing power of people with limited incomes such as people who are on the poverty line and below the poverty line, or people with fixed income and on the other hand. The presence of inflation also affects the amount of production of goods.

Indirectly, the existence of inflation in the economy has a real impact on people's welfare. Therefore, studies on inflation are needed, especially by the government as a policymaker. As stated by [2] the stabilization of various policies to control inflation has benefited the poor and even the rich. Meanwhile, other factors that play a role in poverty are no less important, namely the unemployment rate and economic growth. Both of these things have an impact on poverty that occurs. According to [3], people's prosperity is determined by the level of income they have. To achieve the optimization of people's income, it is necessary to first realize the use of full employment (full employment). If this condition has not been achieved, the level of community welfare is still low. In other words, unemployment will be the cause of the emergence of new poor people, and it will push poverty to increase because unemployment will have an impact on reducing the aggregate income of the community. Meanwhile, economic growth implies an increase in output, the supply of economic goods, and the presence of advanced technology in a country. [4] revealed that economic growth is related to increasing economic capacity to produce goods and services for improving people's welfare. Sustainable economic growth has a significant impact on poverty reduction. One of the strategies that can be applied to tackle the problem of poverty is by increasing economic growth [5].

If we apply the various concepts previously described to Bengkulu Province, we will get an overview of the condition of Bengkulu Province as follows; Bengkulu Province has always been the champion in poverty. In 2015, Bengkulu province became the province with the highest percentage of poor people in Sumatra [6]. This position continues to last until 2017. Meanwhile, the value of district / municipal GRDP in Bengkulu Province continues to increase. Besides, in 2017, Bengkulu Province's total exports grew to reach 73.24 percent compared to data in 2016 with an export value of US \$ 275.25 million, while 2016 was the only US\$ 158.88 million. The coal commodity dominates the export value (US\$ 116.35 million), followed by rubber (US\$ 89.9 million), then CPO with a total export value of US \$ 
57.72 million (https://www.berandang.com/news ). Furthermore, the open unemployment rate decreased in 2016 from 4.91 percent in 2015 to 3.3 percent. Meanwhile, the average inflation rate in the last three years (2015-2017) was maintained at the level of 3.94 percent.

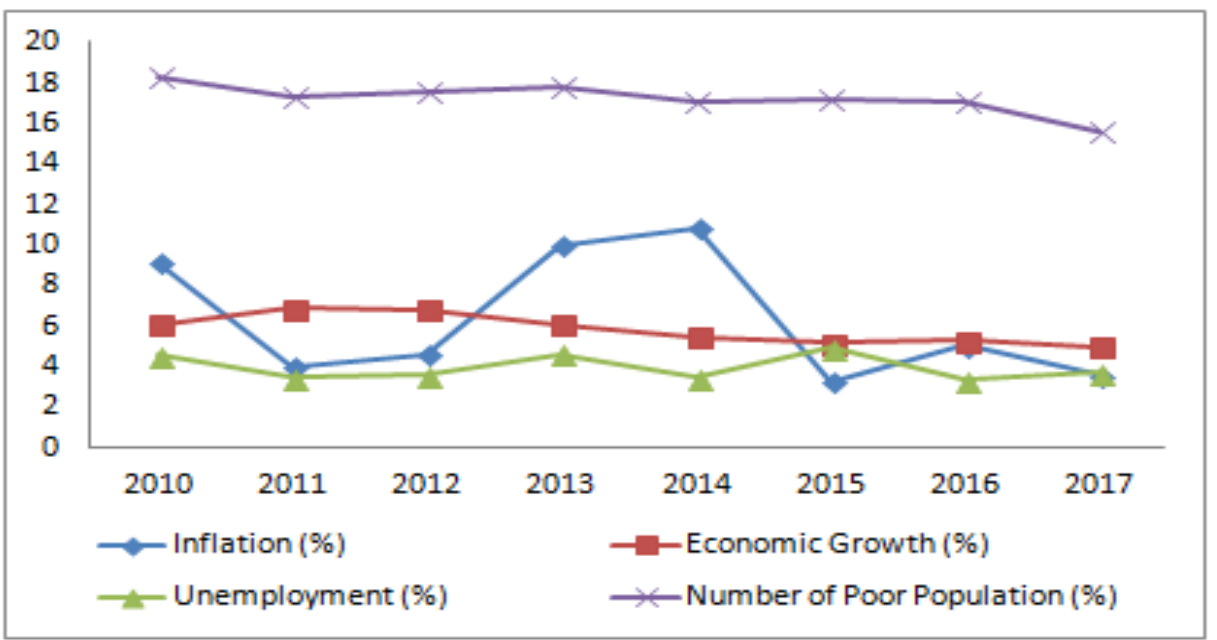

Fig. 1. Progress of Inflation, Economic Growth, Unemployment, and the poor in Bengkulu Province

Although in the last eight years, inflation, unemployment, and the percentage of poor people in Bengkulu Province have a trend that tends to decrease, when compared to other regions, the decline movement is slightly slower. Meanwhile, when viewed from economic growth, the downward trend that occurs raises a big question mark. It is as expressed by [7] in the results of his research that concluded that low inflation rates and high economic growth encourage efficient resource allocation, increase employment opportunities, increase investment, and reduce unemployment and results in a decrease in the poverty rate. However, this condition is a bit contradicting what happened in Bengkulu Province. Figure 1 shows a downward trend in economic growth, but on the other hand, the poverty rate also tends to decline. It can be seen that there are different and contradictory directions, even though this should not be the case when viewed from a developing economic theory. Therefore, this study will prove the influence of economic factors such as inflation, economic growth, and unemployment on poverty in Bengkulu Province.

\section{Literature Review}

Various studies on inflation, unemployment, economic growth, and poverty have been widely disclosed in various empirical evidence from almost all countries in the world. Several literature reviews on this subject are presented as follows. [8] investigated the impact of inflation on poverty in Indonesia, both in urban and rural areas. This study uses the demand theory as a basis for measuring elasticity, hereinafter referred to as the price index for the poor (PIP), and is supported by the National Socioeconomic Survey (SUSENAS) data from BPS. The results showed that in general, the price elasticity of the poor for goods in the form of food commodities was higher than that of non-food commodities. In the food category, prices for food products have a greater impact on poverty levels relative to processed foods, 
beverages, and tobacco. The total elasticity for the per person ratio (headcount ratio), poverty gap ratio, and poverty severity have scores of $2.93,3.99$, and 4.69 , respectively. These figures show that the impact of high prices on the very poor is greater than it is for the poor. Overall, it can be revealed from the results of this empirical study that poor households in urban areas are more vulnerable to economic shocks, especially inflation. The urban poor households will experience a more severe impact due to price fluctuations in prices. Meanwhile, based on the amount of PIP, it shows that inflation has a greater impact on poor households both in urban and rural areas compared to non-poor households.

[9] examined economic growth, unemployment, and poverty in Nigeria through an econometric model in the form of a three-stage least square (3SLS). Using time-series data for 30 years (1980-2010), found empirical results showing that poverty was correlated negatively with economic growth and agricultural production, but positively related to the unemployment rate. Economic growth is also negatively associated with the poverty index and unemployment has a positive relationship to the poverty index and growth. It clarified that low economic growth indicates a sluggish economy, and this has an impact on the ability of the community to access a variety of goods that are increasingly difficult, meaning that new impoverished households or individuals will emerge or poverty levels will increase. Likewise, an increase in the unemployment rate will push the poverty level even higher. It is due to the lower purchasing power due to non-existent or limited sources of income.

Meanwhile, in Pakistan, poverty is assessed through macroeconomic variables in the form of economic growth, investment, inflation, and trade openness. A study on this topic was expressed by [10] through the Auto Regressive Distributed Lag (ARDL) analysis tool and using online data from the World Development Indicators (WDI) for variables other than poverty, while poverty data is measured by the percentage of the population living below the line. poverty, the results obtained in two periods of observation time, namely the short term and the long term. In the long term, it is found that inflation is positively correlated with poverty and is significant at the 1 percent level. This shows that if there is a one percent increase in the price index (inflation) it will increase the individual poverty ratio by 0.38 percent. Furthermore, economic growth has a significant negative effect on poverty. This means, ceteris paribus, that an increase in per capita income of 1000 Pakistani rupees will reduce the percentage of the population living below the poverty line by 2.5 percent. For the investment variable with a value of -0.41 and significant at the 10 percent level, this indicates that investment has a negative effect on poverty in Pakistan, meaning that a 1 percent increase will reduce poverty by 0.4 percent, and trade openness has a positive effect, namely an increase of 0.08 percent. caused by a 1 percent increase in total trade. Meanwhile, for the short term, the relationship between the variables studied shows results that are not different from the long term.

The results of other studies also confirm the effects of inflation, unemployment, and economic growth on poverty. [11] conducted a study on this topic with the research area being Indonesia. By using time series data from 1984-2014 and multiple linear regression analysis tools, the results obtained that inflation has a positive effect, economic growth has a negative effect, and unemployment has a significant positive effect. [12] states that poverty in Central Java that occurred in the 2003-2007 period was significantly influenced by economic growth, unemployment, minimum wages, and education. High economic growth followed by a higher minimum wage and a higher level of education will push the poverty rate down. Likewise, with unemployment, policies that stimulate the creation of more job opportunities so that more workers are absorbed will be able to reduce poverty that occurs in Central Java. Furthermore, [13] presents the results that the unemployment rate, the value of exports and 
imports, and public investment are variables that have a significant negative effect on the poverty rate in Vietnam. Meanwhile, economic growth and public spending have no effect on poverty. Hereinafter, [14] using fixed effect model (FEM) found that economic growth and unemployment rate has positive significant effect on poverty rate in six provinces in Sulawesi Island during 2010-2017.

\section{Methodology}

This study used a computer program in the form of the SPSS 16 program. While the analytical tool used to answer research questions is multiple linear regression models. This analysis technique is considered appropriate because multiple linear regression is an analysis technique that examines the influence between variables in the form of dependent and independent variables using time series data. The characteristics of this analysis technique are by the problems in this study where this study will examine the effect of inflation, unemployment and economic growth (dependent variables) on the poverty variable (independent variable) in Bengkulu Province. This study first of all tests classic asumption in the time series. The data for all variables is taken from BengkuluProvince's Central Statistic Bureau for period 1992-2017. The regression model for this study can be specified below.

Pov $=\beta_{0}+\beta_{1} \operatorname{Inf}+\beta_{2}$ Unm $+\beta_{3}$ EG $+\beta_{3}$ ExG $+e$

Where:

Pov represents poverty level, Inf stands for inflation rate, Unm is the unemployment rate, and EG constitutes economic growth.

$\beta_{0}$ are constant parameters,

$\beta_{1}-\beta_{3}$ are coefficients to be estimated,

e are error term

\section{Empirical Results}

Inflation, economic growth, and unemployment are problems in economic development that can erode people's welfare. The solution to poverty problems is always sought through various approaches, one of which is the macroeconomic variable approach. Poverty, which is defined as a loss of welfare due to limitations in accessing available resources, is closely related to the ability to access these resources with means of fulfilling needs in the form of income. Increasing income can be done through a development process that encourages a high increase in national income and rapid economic growth so that more job opportunities will emerge.

Statistically, the relationship between the three macroeconomic indicators, namely inflation, economic growth, and unemployment on poverty, can be proven for its direction and effect. The estimation results in table 5.9 show that in general, the model used is good enough in explaining the impact of the independent variables (inflation, economic growth, and unemployment) together on poverty, indicated by the value of the coefficient of determination (adjusted R-squared) which is 0,54 . Also, from the notation, the core variables were analyzed to show the direction of influence as expected. Meanwhile, the closeness of the effect of the independent variables and the dependent variable that show by the high $F$ statistical value with 
a 99 percent confidence level, indicates a very close influence between the independent variables and the dependent variable.

Table 1. The Results of OLS regression

\begin{tabular}{lrrr}
\hline Variable & Coefficients & t & Sig. \\
\hline Inflation rate & $0.081050^{*}$ & 1.849473 & 0.0779 \\
Economic growth & $-1,627886^{* * *}$ & -2.961618 & 0.0072 \\
Unemployment rate & $1,708501^{* * *}$ & 4.123315 & 0.0004 \\
\hline Adjusted R-squared & & 0,542774 & \\
F statistik & & 10,89252 & \\
Sig. & & 0,000137 & \\
\hline
\end{tabular}

The $\mathrm{t}$ statistic results at the 90 percent confidence level show that the inflation rate has a significant effect on the poverty rate variable. A regression coefficient of 0.08 explains that every 1 percent increase in the inflation rate will encourage an increase in the poverty rate in Bengkulu Province by 0.08 percent, assuming that the other variables are constant. As stated by Powers [15], actually inflation and poverty are inseparable friends, the relationship between the two is positive, if inflation in a region increases, it will also be followed by increasing in the level of poverty in that area, assuming that poverty is count in terms of consumption. Besides, [16] also adds that the way inflation causes the poverty rate to increase is through the real wage rate. The amount of income that a person receives will decrease by the value of inflation at the time it is spending.

The same result is given by the economic growth variable. Based on a 99 percent confidence level, the regression results in table 5.9 show that changes in the rate of economic growth have a significant effect on poverty in Bengkulu Province. The economic growth that moves up by 1 percent will reduce the percentage of poor people in Bengkulu Province by 1.62 percent, ceteris paribus. Economic growth plays a prominent role in poverty alleviation. The role of economic growth is through increasing employment opportunities, increasing labor productivity, and rising real wages. There is an inverse relationship between economic growth and poverty, as revealed by [17] that economic growth will drive economic sectors to create job opportunities so that there will be many new income streams so that people's purchasing power increases.

To create high economic growth, it is necessary to invest in human resources. Although there is a significant relationship between economic growth and poverty, according to [17], it is necessary to be careful in analyzing the relationship between the two because there are differences in the distribution of income. Even though economic growth is not enough to alleviate poverty, usually economic growth is something that is needed. Even though the economic growth of a region is good enough, it will not be meaningful without being accompanied by equitable development. However, many economists agree that economic growth, in the long run, can reduce the absolute poverty rate[18].

Meanwhile, unemployment is another necessary variable contributing to changes in poverty conditions in Bengkulu province. Table 1 statistically proves that the open unemployment rate affects the poverty rate in Bengkulu province. An increase in the unemployment rate of 1 percent will cause an increase in the percentage of poor people in Bengkulu province by 1.71 percent, with other variables considered constant. This condition implies the behavior of most households in Bengkulu Province who have a liquidity constraint. The point is that these households still have a large dependence on their current salary/wages income. Losing a job or delaying the opportunity to work will reduce income 
also unsupported other sources of income such as savings will drag it into the low consumption level of society, and this will be worse if experienced by groups of people whose income levels are slightly above the poverty line, then the absence of a job or their status as unemployed will easily shift their position to become a group of the poor.

\section{Conclusion and Recommendations}

The results of research in Bengkulu Province in the observation period from 1992-2017 indicate that inflation, economic growth, and unemployment have a significant effect on the poverty rate in Bengkulu Province. Poverty for the proportion of poor people's shows a reaction that shows the influence of external factors in the form of inflation in the same direction as unemployment. However, the effect is showed in proportion to economic growth.

Poverty reduction is pivotal in the goals of economic development in every region. The regional government always sets its policy direction by prioritizing poverty reduction as a target that must achieve. The results of this study reveal a declining purpose of economic growth and an increasing function of unemployment and inflation. Nobody can deny that high economic growth will create an increase in people's welfare. Likewise, people's purchasing power will terminate by rising prices (inflation), as well as a lack of absorption of the labor market, then create new poor people as a consequence of losing an income, and it is tough to fulfill their daily needs.

Therefore, based on the empirical results, the aims of the Bengkulu Province government to reduce the level of poverty should encourage the creation of high economic growth and maintain the movement of the price level, especially the prices of staple goods that remain within the purchasing power of the people in general. Apart from that, the government can make programs that can encourage the creation of great job opportunities in Bengkulu Province.

\section{References}

[1] Wilson, L. Inflation, the Hidden Tax. L.D. Wilson Consultants, Inc ( 2015).

[2] Bruno, M., and Easterly, W. Inflation Crises and Long-Rong Growth. Journal of Monetary economics, vol. 41, pp. 3-26 (1998).

[3] Mankiw, Gregory. Teori Makro Ekonomi, edisi ke-6. Erlangga, Jakarta (2007).

[4] Herwartz, H., and Niebuhr, A. Growth, Unemployment and Labour Market Institutions: Evidance from a Cross-Section of EU Regions. Applied Economics, vol. 43, no.30, pp. 4663-4676 (2011).

[5] Lopez, J. Humberto. Pro-growth, pro-poor: is there a tradeoff?. Policy Research Working Paper Series no.3378, The World Bank (2004).

[6] Badan Pusat Statistik (BPS). Data dan Informasi Kemiskinan, berbagai edisi. Kantor Statistik Provinsi Bengkulu (1990-2018).

[7] Gylfason, T. Output Gains from Economic Stabilization. Journal of Development Economics, vol. 56, pp. 81-96 (1998).

[8] Sugema, Iman, Toni Irawan, Denley Adipurwanto, Ade Holls, dan Toni Bakhtiar. The Impact of Inflation on Rural Poverty in Indonesia: an Econometrics Approach. International Research Journal of Finance and Economics ISSN 1450-2887 Issue 58 (2010) 
[9] O, Anuolam Moses., E, Anuforo E. An Econometric Examination of Growth, Unemployment, and Poverty in Nigeria. West African Journal of Industrial \& Academic Research, vol. II, no. I (June), pp. 117-133 (2014).

[10] Chani, Muhammad Irfan., Pervaiz, Zahid., Jan, Sajjad Ahmad., Ali, Amjad., Chaudhary, Amatul R. Poverty, Inflation and Economic Growth: Empirical Evidence From Pakistan. Munich Personal RePec Archive (MPRA), no. 34290. (2011).

[11] Suhendah,Elvi. Pengaruh Pertumbuhan Ekonomi, Pengangguran, dan Inflasi terhadap kemiskinan di Indonesia Tahun 1998-2014. Tesis. STKIP PGRI Sumatera Barat. (2016).

[12] Prastyo, Adit A. Analisis Faktor-Faktor yang Mempengaruhi Tingkat Kemiskinan (studi Kasus 35 kabupaten/Kota di Jawa Tengah tahun 2003-2007). Skripsi. Universitas Diponegoro, Semarang (2010).

[13] Quy, Nguyen Hoang. Relationship between Economic Growth, Unemployment and Poverty: Analysis at Provincial Level in Vietnam. International Journal of Economics and Finance, vol. 8, no. 12, pp. 113-119 (2016).

[14] Badu, Roflan R., Canon, Syarwani., and Akib, Fitri Hadi Yulia. The Impact of Economic Growth and Unemployment Rate on Poverty in Sulawesi. Jambura Equilibrium Journal (JEJ), Vol. 2 Issue 1, pp. 25-33 (2020).

[15] Powers, Elisabeth T. Inflation, Unemployment, and Poverty Revisited. Economic Review, issue Q III, pp. 2-13 (1995).

[16] Cardoso, Eliana. Inflation and Poverty. NBER Working Papers Series No. 4006 (1992).

[17] Marinko, S., and Romina, P.D. Poverty and economic Growth: A Review. Technological and economic Development of Economy, Vol. 22 No. 1, pp.156-175 (2015).

[18] Al-Habees, M.A., and Rumman, A. M. The Relationship Between unmeployment and Economic growth in Jordan and some Arab Countries. World Applied Sciences Journal, Vol. 2 No.5, pp.673-680 (2012). 